\title{
ANALISIS STRUKTUR MAJAS SELOKO HUKUM ADAT SEBAGAI BENTUK EKSPRESI SIMBOLIK NILAI-NILAI RELIGIUS MASYARAKAT MELAYU JAMBI
}

\author{
Erlina Zahar ${ }^{3}$
}

\begin{abstract}
This study aims to gain a deep understanding of: 1) The structure of the custom of Seloko adat law as a form of traditional expression of jambi Malay society, and (2) the function of majas in custom seloko text texts on Melayu Jambi society. This research is qualitative descriptive by using method hermeneutic structural analysis. The data in this study are religious values in Seloko Adat, sourced from seloko lines in a collection of custom seloko text. Primary data sources were obtained from Jambi Customary Institution documents and secondary sources derived from related researches obtained from customary stakeholder books and information or those who knew about Seloko Adat on Jambi Community. The results of this study include: 1) In general, the religious values contained in the SAMJ majoric elements, reflected the use of the type of parable of majesty, metaphoric majesty, personification of majesty, hyperbole majesty, and repetitive masters. The expressions contained in the SAMJ are symbolic or indirect, and 2) In general the religious values of the aspects of understanding the symbols in the SAMJ Jambi text are reflected in religious symbols, custom symbols, and languages. The understanding of these symbols in the text of the Jambi Malay customs center illustrates the strong belief of the Malay Jambi people against the customary relationship with the Islamic religion, so that customary symbols refer to Islam. Understanding the symbols are related to aspects of belief, appreciation, knowledge and practice of Islamic teachings in the life of the Jambi Malay community.
\end{abstract}

Keywords: Figure of Speech, Seloko Adat Law, Symbolic Expression, Religious Values.

\footnotetext{
${ }^{3}$ Dosen Program Studi Pendidikan Bahasa dan Sastra Indonesia Universitas Batanghari
} 


\section{PENDAHULUAN}

Dewasa ini, manusia Indonesia cenderung mengikuti gaya hidup baru yang trendy dan menempatkan nilainilai baru dalam keberhasilannya. Sampai pada batas tertentu nilai-nilai tersebut telah merusak nilai-nilai tradisional yang sebelumnya dipegang teguh dan diyakini kebenarannya dalam masyarakat. Nilai yang dahulu mementingkan kebersamaan, kini didominasi oleh nilai individualistis, nilai yang meletakkan unsur spritual berganti dengan unsur materi (Aldin, 2006, Thoby, 2009, dan Semiawan, 2012:1). Fenomena ini juga muncul dalam kehidupan masyarakat Melayu Jambi. Tradisi gotong royong dalam membangun rumah, pesta perkawinan, menggarap sawah atau ladang sekarang sudah mulai hilang. Selain itu, penyerapan ilmu dan teknologi yang canggih tanpa filter yang tangguh dapat mengakibatkan pergeseran dan perubahan pola pikir serta perilaku yang melecehkan nilai agama, nilai moral, dan norma-norma adat yang hidup dalam masyarakat. Sebagai akibatnya, generasi muda akan kehilangan nilai-nilai luhur, dan lambat laun mereka akan kehilangan kepribadian dan jati dirinya (Yundiafi, 2010: 1).

Di sisi lain, kelahiran sebuah karya sastra bersumber dari kehidupan yang bertata nilai dapat memberi sumbangan bagi terbentuknya tata nilai dalam masyarakat. Sastra sebagai produk kehidupan, kaya dengan berbagai nilai seperti nilai-nilai religius, nilai budaya, nilai pendidikan, nilai moral, dan lain-lain (Suyitno, 1984:3). Hal ini dapat terlihat dari berbagai teks sastra Melayu klasik seperti teks seloko adat pada masyarakat Melayu Jambi. Sehubungan dengan hal ini, N.H Dini (1912:2) menjelaskan bahwa dalam sastra Melayu terekam pantun, sajak, seloka, dan peribahasa yang mengandung nilai-nilai luhur yang dapat dijadikan teladan hidup manusia sampai sekarang. Nilai-nilai luhur tesebut tidak akan terkikis oleh geseran waktu. Bila dikaitkan dengan kajian dalam penelitian ini, pernyataan tersebut menunjukkan bahwa nilai-nilai luhur dalam teks seloko adat Melayu Jambi akan bertahan sampai kapan pun.

Ungkapan-ungkapan seloko adat pada masyarakat Melayu Jambi merupakan kodifikasi nilai-nilai kehidupan masyarakat Melayu Jambi yang mencerminkan nilai-nilai religius yang berkaitan dengan hubungan manusia dengan Tuhan, hubungan manusia dengan alam, hubungan manusia dengan masyarakat, dan nilai religius dalam hubungan manusia dengan diri sendiri. Nilai-nilai religius dalam kehidupan sosial masyarakat Melayu Jambi tercermin dalam seloko adat Jambi: Adat bersendi Syarak, Syarak bersendi Kitabullah (Syam, 2002:18). Usaha merumuskan atau mengejawantahkan pendidikan nilainilai religius tersebut melalui ungkapan-ungkapan seloko adat merupakan kegiatan simbolik yang dilakukan oleh masyarakat Melayu Jambi. Kegiatan simbolik merumuskan seloko-seloko adat merupakan rangkaian simbolik dalam jaring-jaring pengalaman manusia. Simbol-simbol yang sarat dengan makna filosofis terdapat dalam seloko adat sebagai pengungkapan nilai-nilai 
religius. Hal ini menunjukkan bahwa manusia terlibat dalam suatu jalinan simbol-simbol yang diungkapkan melalui mitos, religi, adat istiadat, bahasa, seni, sejarah, dan ilmu pengetahuan (Cassirer, 1979:315).

Pentingnya penelitian ini didasarkan atas pertimbangan: (1) Penelitian ungkapan tradisional seloko adat penting dilakukan khususnya struktur majas sebagai ekspresi simbolik nilai-nilai religius pada masyarakat Melayu Jambi belum pernah dikaji secara mendalam, (2) Pelestarian terhadap nilai-nilai kearifan lokal ungkapan tradisional seloko adat masyarakat Melayu Jambi perlu dilakukan agar tidak punah tergeser oleh nilai-nilai lain yang bertentangan dengan budaya Melayu Jambi, dan (3) Teks ungkapan tradisional seloko adat Melayu Jambi telah banyak terdokumentasi, namun sampai saat ini belum banyak dianalisis, sehingga penggalian struktur majas seloko hukum adat sebagai bentuk ungkapan tradisional di dalamnya belum dapat dipahami secara menyeluruh oleh pembacanya.

Adapun tujuan penelitian ini adalah (1) untuk mendapatkan pemahaman yang mendalam tentang struktur majas seloko hukum adat sebagai bentuk ungkapan ekspresi simbolik nilai religius masyarakat Melayu Jambi, dan (2) untuk mendapatkan pemahaman yang mendalam tentang fungsi majas dalam teks seloko hukum adat sebagai bentuk ekspresi simbolik nilai religius pada masyarakat Melayu Jambi.

\section{METODE PENELITIAN}

Penelitian yang peneliti laksanakan ini termasuk penelitian kualitatif dengan pendekatan struktual yang terintegrasi dengan metode analisis isi. Metode analisis isi pada penelitian ini merupakan upaya pemahaman terhadap unsur-unsur ekstrinsik seloko adat yang meliputi nilai-nilai religius. Metode ini dipadukan dengan teknik telaah struktural hermeneutik guna mengungkap makna tersembunyi atau tersamar yang mengandung nilai-nilai religus dalam teks seloko adat Jambi.

Teknik pengumpulan data pada penelitian ini adalah dokumentasi, wawancara, dan observasi. Data yang dikumpulkan berupa larik-larik seloko adat pada masyarakat Melayu Jambi yang telah didokumentasikan oleh lembaga adat Jambi. Adapun data primer pada penelitian ini bersumber dari dokumen-dokumen lembaga adat Jambi dalam buku Pokok-Pokok Adat Jambi Sembilan Lurah: Dasar-Dasar Hukum Ada dan Sastra Adat Jambi (Syam, 2002:1). Sedangkan, data sekunder pada penelitian ini bersumber dari informasi yang diperoleh dari buku-buku dan informasi pemangku adat atau pihakpihak yang mengetahui tentang seloko adat pada masyarakat Jambi.

\section{HASIL PENELITIAN DAN PEMBAHASAN}

Berdasarkan temuan hasil penelitian, unsur majas yang terdapat pada seloko hukum adat meliputi 5 jenis majas, yaitu (1) simile, (2) metafora, (3) personofikasi, hiperbola, dan (5) repetisi. 


\section{Contoh 1. Majas Perumpamaan (Simile)}

Terang bagai bulan, siang bagai matahari

"Terang bagai bulan, siang bagai matahari"

Artinya: Terang atau jelas seperti cahaya bulan dan siang seperti matahari.

Pemakaian bahasa kiasan ini ditujukan untuk suatu pembuktian yang ditemukan dalam proses hukum adat. Dalam teks seloko tersebut perumpaan terkait dengan bukti-bukti yang sudah jelas atau terang. Hal ini tentu mengacu pada sifat cahaya bulan dan matahari. Bila dicermati secara mendalam nilai-nilai religius yang terkandung dalam struktur majas SHA ini terkait dengan aturan hukum yang sesuai dengan tuntunan agama. Aturan hukum tersebut terkait dengan pengambilan keputusan hukum harus berdasarkan bukti-bukti yang jelas. Kebenaran bukti-bukti tersebut harus dapat dipertanggungjawabkan. Dalam menjatuhkan hukuman kepada seseorang dalam teks SHA diharuskan memiliki bukti yang jelas sesuai fakta-fakta yang ada sehingga salah atau benarnya. Jadi dapat disimpulkan nilai-nilai religius yang terkandung dalam majas perumpamaan tersebut yaitu pembuktian yang jelas dalam menghukum.

Temuan tentang nilai-nilai religius dalam struktur majas SHA dapat dilihat dalam teks seloko dengan jenis majas metafora, seperti kutipan data di bawah ini:

\section{Contoh 2. Majas Metafora}

Syarak berbuhul mati, adat berbuhul sentak

"Syarak berbuhul mati, adat berbuhul sentak"

Artinya: Hukum agama bersifat tetap (statis) tidak dapat diubah. Sedangkan, hukum adat bersifat longgar (dinamis) dapat diubah sesuai kondisi.

Pada teks SHA tersebut pemakaian majas metafora diimpilisitkan karena pengarang langsung menyebutkan bagian pokok yang ditandai dengan penyamaan agama dan adat dengan tali tanpa menyebut talinya. Majas ini digunakan untuk mengungkapkan bahwa aturan-aturan hukum agama sifatnya tetap atau ketat yang sulit atau bahkan tidak dapat diubah sedangkan hukum adat ikatanya agak longgar sehingga lebih mudah diubah. Jadi, majas metafora dalam teks seloko adat tersebut bermakna bahwa hukum agama tidak dapat diubah, sedangkan hukum adat dapar berubah. Nilai-nilai religius yang tercermin dari majas ini terkait dengan aspek keyakinan terhadap aturan-aturan agama. Oleh karena itu, nilai-nilai religius dalam struktur majas ini berkaitan dengan hubungan manusia dengan Tuhan dan hubungan manusia dengan masyarakat.

Contoh 3. Majas Personifikasi

Syarak mengato, adat memakai

"Syarak mengatakan, adat melakukan"

Artinya: Agama mengatakan dan adat melaksanakan. 
Teks seloko adat menggunakan majas personifikasi. Hal ini terlihat dari ciri majas ini yang melekatkan sifat-sifat manusia atau insan pada barang yang tidak bernyawa atau ide yang abstrak. Dalam teks seloko adat ini, sifat manusia yang dilekatkan yaitu "mengatakan" dan "melakukan" pada ide abstrak yakni "syarak" dan "adat". Kata syarak yang mengacu pada konsep hukum agama Islam dan adat berarti hukum adat. Jadi, segala hal yang telah diatur dalam hukum agama harus dilaksanakan oleh hukum adat. Hal ni mencerminkan nilai-nilai religius yang terkait dengan hubungan manusia dengan Tuhan.

\section{Contoh 4. Majas Hiperbola}

Pipih tidak bersudut boleh dilayangkan,

Bulat tidak bersanding boleh digulingkan

"Pipih tidak bersudut boleh dilayangkan,

Bulat tidak bersanding boleh digulingkan"

Artinya: Mencari kesepakatan dalam memutuskan suatu masalah dan bila sudah sepakat baru diputuskan.

Teks seloko tersebut menggunakan majas hiperbola. Penggunaan majas ini terlihat dari ungkapan yang melebih-lebihkan sifat atau ukuran sesuatu benda. Pada bait seloko di atas terdapat ungkapan bentuk yang pipih dengan bentuk tidak bersudut, pada bait seloko tersebut sebenarnya sudah bermakna sama, yaitu kalau pipih pasti tidak bersudut. Begitu pula kata bulat sudah jelas tidak bersanding. Namun dalam teks SHA tersebut kedua digunakan dalam baris yang sama. Majas hiperbola digunakan sebagai bentuk penegasan bahwa suatu kesepakatan, kalau sudah jelas disepakai baru dapat diputuskan agar semua pihak menyetujuinya dengan ikhlas. Nilai religius yang tercermin dari majas hiperbola ini terkait kesungguhan hati dalam bersepakat.

\section{Contoh 5. Majas Repetisi}

Tibo diperut idak dikempeskan

Tibo dimato idak dipicingkan

"Tibo diperut tidak dikempeskan Tibo dimato tidak dipejamkankan"

Artinya: Menghukum harus adil tanpa pilih kasih.

Teks SHA tersebut menggunakan majas repetisi, hal ini terlihat dari pengulangan kata pada bait-bait seloko tersebut. Pengulangan kata-kata tibo "tiba" dan kata idak "tidak" bertujuan untuk menyakinkan pembaca atau mempertegas maksud ungkapan. Bila dikaitkan dengan konteks nilai-nilai religius, maka pengulangan kata dalam bait-bait SHA bertujuan untuk menanamkan nilai-nilai yang terkandung dalam makna simboliknya, yakni nilai keadilan dalam memutuskan suatu perkara.

\section{Nilai-Nilai Religius dalam Majas Perumpamaan (Simile)}

Salah satu jenis majas atau bahasa kias yang ditemukan dalam penelitian ini, yaitu majas simile (perumpamaan). Simile berasal dari bahasa Latin yang bermakna "seperti". Majas ini termasuk majas perbandingan, yaitu majas yang secara eksplisit membandingkan dua hal yang pada hakikatnya berbeda namun sengaja dianggap sama. Majas 
simile atau perumpamaan yang terdapat dalam seloko adat secara eksplisit diungkapkan dengan pemakaian kata bagai dan bak sebagai cirinya. Bahasa kiasan jenis ini dapat dilihat dalam contoh berikut:

\section{Contoh 1. Majas Perumpamaan (simile)}

Terang bagai bulan, siang bagai matahari

"Terang bagai bulan, siang bagai matahari"

Artinya: Terang atau jelas seperti cahaya bulan dan siang seperti matahari.

Pemakaian bahasa kiasan ini ini ditujukan untuk suatu pembuktian yang ditemukan dalam proses hukum adat. Dalam teks seloko tersebut perumpamaan terkait dengan buktibukti yang sudah jelas atau terang. Hal ini tentu mengacu pada sifat cahaya bulan dan matahari. Bila dicermati secara mendalam nilai-nilai religius yang terkandung dalam stuktur majas SHA ini terkait dengan komponen etika. Komponen religiusitas berhubungan dengan aturan-aturan untuk membimbing perilaku interpersonal dalam membedakan yang benar dengan yang salah harus disertai bukti yang dapat dipertanggungjawabkan. Dalam menjatuhkan hukuman kepada seseorang dalam teks SHA diharuskan memiliki bukti yang jelas sesuai fakta-fakta yang ada sehingga salah atau benarnya suatu hal dapat dibuktikan. Jadi, dapat disimpulkan nilai-nilai religius yang terkandung dalam majas perumpamaan terebut adalah nilai pembuktian yang jelas dalam memutus suatu perkara.

\section{Nilai-Nilai Religius dalam Majas Metafora}

Metafora merupakan bentuk majas perbandingan atau perumpamaan yang tidak menggunakan kata-kata pembanding. Metafora melihat sesuatu dengan perataraan benda yang lain. Jenis majas metafora merupakan majas yang paling banyak terdapat dalam larik-larik seloko adat. Nilai-nilai religius dalam struktur majas SHA dapat dilihat dalam teks seloko dengan jenis majas metafora, seperti kutipan data berikut:

\section{Contoh 2. Majas Metafora}

Syarak berbuhul mati, adat berbuhul sentak

"Syarak berbuhul mati, adat berbuhul sentak"

Artinya: Hukum agama bersifat tetap (statis) tidak dapat diubah. Sedangkan, hukum adat bersifat longgar (dinamis) dapat diubah sesuai kondisi.

\section{Pada teks SHA tersebut pemakaian majas metafora diimpilisitkan karena pengarang} langsung menyebutkan bagian pokok yang ditandai dengan penyamaan agama dan adat dengan tali tanpa menyebut talinya. Majas ini digunakan untuk mengungkapkan bahwa aturan-aturan hukum agama sifatnya tetap atau ketat yang sulit atau bahkan tidak dapat diubah sedangkan hukum adat ikatannya agak longgar sehingga lebih mudah diubah. Jadi, majas metafora dalam teks seloko adat tersebut bermakna bahwa hukum agama tidak dapat 
diubah sedangkan hukum adat dapat berubah. Nilai-nilai religius yang tercermin dari majas ini terkait dengan aspek keyakinan terhadap aturan-aturan agama.

Keyakinan dalam majas ini tercermin dari ungkapan berbuhul mati dan berbuhul sentak. Hukum agama diibarat ikatan tali kalau berbuhul mati pasti tidak dapat dilepas. Berbeda dengan hukum adat yang diibaratkan berbuhul sentak, suatu ikatan yang sifatnya longgar jadi masih dapat dilepas. Hal ini mencerminkan nilai-nilai religius tentang keyakinan terhadap aturan hukum agama itu bersifat tetap, mengikat, dan ketat sifatnya. Sedangkan, hukum adat bersifat longgar dapat diubah atau dilepas. Kepercayaan kepada hukum agama yang berumber dari Alquran dan Hadist nabi merupakan salah satu rukun iman yakni percaya kepada kitab suci Alquran. Dengan demikian, nilai-nilai religius dalam struktur majas ini berkaitan dengan hubungan manusia dengan Tuhan dan hubungan manusia dengan masyarakat. Selanjutnya, majas metafora yang mengandung nilai-nilai religius, yaitu:

Batirai api, babantal tumang "Bertirai api, berbantal tumang

bakalambu asap, bakain basah berkalambu asap, berkain basah

babadan litak, bebaju peluh berbadan litak, berbaju peluh"

Artinya: Tanggung jawab dalam pesta yang dikelilingi api, asap, berbaju basah berkeringat dan berbadan capek atau letih.
Titian tereh bertanggo batu

"Titian teras bertanggo batu"

Artinya: Hadist Nabi dan
Kitabullah (Alquran)

Cermin gedang nan tidak kabur

"Cermin besar yang tidak kabur"

Artinya: Tradisi lama yang terbukti kebenaran dan kebaikannya.

Bait seloko di atas merupakan salah satu contoh pemakaian majas jenis majas metafora. Majas ini merupakan perbadingan dengan perantaraan benda. Majas metafora pada contoh di atas membandingkan dua hal yakni kata tirai dengan api, kata bantal dengan tumang, kata kelambu dengan asap, dan kata baju dengan peluh. Kedua hal yang diperbandingkan pada hakekatnya berbeda tapi dianggap sama. Pada seloko adat Melayu Jambi bait pertama Titian tereh bertanggo batu, merupakan perbandingan yang digunakan untuk hukum agama yang bersumberkan Al-Quran dan hadist sebagai pedoman yang jelas. Sedangkan bait kedua "Cermin gedang nan tidak kabur" memperbandingkan tradisi lama yang terbukti kebenaran dan kebaikannya. Dengan demikian, nilai-nilai religius yang tercermin dari majas ini terkait dengan simbolisasi hubungan manusia dengan masyarakat dan hubungan manusia dengan Tuhan.

\section{Nilai-Nilai Religius dalam Majas Personifikasi \\ Bahasan selanjutnya terkait dengan nilai-nilai religius yang terpancar dari teks seloko adat}


mengunakan majas personifikasi. Majas personifikasi merupakan bahasa kiasan yang memperbandingkan atau menyamakan benda dengan manusia atau sifat-sifat manusia. Dalam teks seloko adat pemakaian majas ini dapat dilihat pada contoh di bawah ini:

Contoh 3. Majas Personifikasi

Syarak mengato, adat memakai

"Syarak mengatakan, adat melakukan"

Artinya: Agama mengatakan dan adat melaksanakan.

Pada bait seloko di atas terlihat dari ciri majas personifikasi, yakni melekatkan sifat-sifat manusia atau insan pada barang yang tidak bernyawa atau ide yang abstrak. Dalam teks seloko adat ini, sifat manusia yang dilekatkan, yaitu "mengatakan" dan "melakukan" pada ide abstrak yakni "syarak" dan "adat". Kata syarak yang mengacu pada konsep hukum agama Islam dan adat berarti hukum adat. Jadi, segala hal yang telah diatur dalam hukum agama harus dilaksanakan oleh hukum adat. Hal ni mencerminkan nilai-nilai religius yang terkait dengan hubungan manusia dengan Tuhan.

\section{Nilai-Nilai Religius dalam Majas Hiperbola}

Hiperbola merupakan jenis majas yang mengandung pernyataan atau ungkapan yang melebihlebihkan apa yang sebenarnya baik jumlah, ukuran maupun sifatnya. Pernyataan yang berlebih-lebihan tersebut bertujuan untuk memberikan penekanan, meningkatkan kesan, dan pengaruh terhadap pernyataan tersebut.

\begin{abstract}
Nilai-nilai religius yang tercermin dalam struktur majas hiperbola dapat dilihat dalam kutipan data berikut:
\end{abstract}

Pipih tidak bersudut boleh dilayangkan,

Bulat tidak bersanding boleh digulingkan

"Pipih tidak bersudut boleh dilayangkan,

Bulat tidak bersanding boleh digulingkan"

Artinya: Mencari kesepakatan dalam memutuskan suatu masalah dan bila sudah sepakat baru diputuskan.

Teks seloko tersebut menggunakan majas hiperbola. Penggunaan majas ini terlihat dari ungkapan yang melebih-lebihkan sifat atau ukuran sesuatu benda. Pada bait seloko di atas terdapat ungkapan bentuk yang pipih dengan bentuk tidak bersudut, pada bait seloko tersebut sebenarnya sudah bermakna sama yaitu kalau pipih pasti tidak bersudut. Begitu pula kata bulat sudah jelas tidak bersanding. Namun dalam teks SHA tersebut kedua digunakan dalam baris yang sama. Majas hiperbola digunakan sebagai bentuk penegasan bahwa suatu kesepakatan, kalau sudah jelas disepakai baru dapat diputuskan agar semua pihak meneyetujuinya dengan ikhlas. Nilai religius yang tercermin dari majas hiperbola ini terkait kesungguhan hati atau keikhlasan dalam bersepakat. 


\section{Nilai-Nilai Religius dalam Majas Repetisi}

Majas repetisi merupakan majas yang memanfaatkan perulangan kata sebagian atau seluruhnya. Nilai-nilai religius yang tercermin dari majas ini dapat dilihat dalam bait seloko berikut:

\section{Contoh 5. Majas Repetisi}

Tibo diperut idak dikempeskan

Tibo dimato idak dipicingkan

"Tibo diperut tidak dikempeskan Tibo dimato tidak dipejamkankan"

Artinya: Menghukum harus adil tanpa pilih kasih.

Pengulangan kata-kata tibo
"tiba" dan kata idak "tidak"
bertujuan untuk menyakinkan
pembaca atau mempertegas maksud
ungkapan. Bila dikaitkan dengan
konteks nilai-nilai religius, maka
pengulangan kata dalam bait-bait
SHA bertujuan untuk menanamkan
nilai-nilai yang terkandung dalam
makna simboliknya, yakni nilai
keadilan dalam memutuskan suatu
perkara.

\section{KESIMPULAN}

Berdasarkan hasil penelitian di atas, maka dapat dapat disimpulkan sebagai berikut:

1. Secara umum nilai-nilai religius yang terkandung dalam unsur majas SAMJ, tercermin pemakaian jenis majas simile, majas metafora, majas personofikasi, majas hiperbola, dan majas repetisi. Ungkapanungkapan yang terdapat dalam SHA bersifat simbolik atau tidak langsung. Nilai-nilai religius yang terkandung dalam majas simile terkait teguran, kritikan, dan larangan perilaku yang bertentangan dengan hukum adat. Nilai-nilai religius yang terkandung dalam majas metafora terkait dengan hukum agama tidak dapat diubah sedangkan hukum adat dapat berubah. Nilai-nilai religius yang terkandung dalam majas hiperbola terkait nilai kesungguh-sungguhan atau keikhlasan, tanggung jawab dalam pelaksanaan aturan hukum. Nilainilai religius yang terkandung dalam majas personifikasi terkait dengan nilai keyakinan terhadap aturan hukum agama dan hukum hukum adat. Nilai-nilai religius yang terkandung dalam majas repetisi terkait dengan penanaman nilai-nilai religius dalam kehidupan keluarga dan masyarakat.

2. Secara umum nilai-nilai religius dari aspek pemahaman simbolsimbol dalam teks SHA Jambi tercermin dari simbol-simbol agama, simbol adat, dan bahasa. Pemahaman simbol-simbol tersebut dalam teks seloko adat Melayu Jambi tergambar kuatnya kepercayaan masyarakat Melayu Jambi terhadap hubungan adat dengan agama Islam, sehingga simbol-simbol adat mengacu pada agama Islam. Pemahaman simbolsimbol tersebut terkait dengan aspek keyakinan, penghayatan, pengetahuan, dan pengamalan ajaran agama Islam dalam kehidupan masyarakat Melayu Jambi.

Berdasarkan kesimpulan dan implikasi penelitian tentang nilai-nilai 
religius yang terkandung dalam unsur tema, diksi, citraan majas, serta pemahaman simbol-simbol dalam SHA, dapat sarankan hal-hal sebagai berikut:

1. Seloko adat Melayu Jambi yang mengandung nilai-nilai religius dapat direkomendasikan sebagai bahan ajar dalam pengajaran Bahasa dan Sastra Daerah sebagai Mulok di setiap jenjang pendidikan di provinsi Jambi. Bahan ajar pengajaran Bahasa dan Sastra yang dikaitkan dengan dengan nilai-nilai lokal sebagai bentuk kearifan lokal masyarakat Melayu Jambi memungkinkan siswa menyerap materi pelajaran lebih baik.

2. Adanya relevansi antara nilainilai religius dalam SHA dengan nilai-nilai luhur yang ingin dicapai dalam pendidikan karakter atau budi pekerti dalam kurikulum 2013. Atas dasar itu, temuan penelitian ini dapat berkontribusi dalam pengembangan pendidikan karakter. Oleh karena itu, perlu direkomendasikan kepada guru agar mengolaborasikan pengajaran Bahasa dan Sastra dengan pendidikan karakter.

3. Nilai-nilai religius dalam SHA merupakan cerminan nilai-nilai luhur yang menjadi acuan masyarakat Melayu Jambi terutama generasi mudanya untuk bersikap, berperilaku, dan berpikir dalam kehidupan sehari-hari berdasarkan syariat Islam.

4. Saran untuk Program Studi Pendidikan Bahasa dan Sastra Indonesia dan Daerah, dapat menjadikan sastra daerah seperti SHA sebagai bahan kajian atau penelitian di samping karya sastra
Nasional dan Internasional. Hal ini bertujuan untuk pelestarian dan pewarisan nilai-nilai budaya yang terkandung dalam karya sastra daerah sebagai aset kebudayaan lokal. Seloko adat Melayu Jambi merupakan simbol budaya daerah masyarakat Melayu Jambi, sehingga perlu pemertahanan budaya lokal dari pembauran dengan budaya asing.

5. Nilai-nilai religius SHA mencerminkan kepecayaan dan pandangan hidup Masyarakat Melayu Jambi yang terkait dengan hubungan manusia dengan Tuhan, hubungan manusia dengan masyarakat, dan hubungan manusia dengan Alam. Hal ini berimplikasi pada pengabdian kepada Tuhan, pengabdian kepada masyarakat, dan pengabdian terhadap keutuhan wilayah. Untuk itu direkomendasikan kepada pemerintah daerah agar menjadikan nilai-nilai religius yang tercermin dalam pandangan hidup masyarakat Melayu Jambi sebagai konsep kebijakan pembangun daerah terutama pembangunan mental dan spiritual masyarakat.

6. Bagi pemerhati budaya Melayu Jambi, penelitian ini dapat dijadikan salah satu referensi dalam memahami nilai-nilai religius yang terkandung dalam SHA sebagai sastra lisan yang disampaikan dalam bentuk peribahasa sebagai salah satu strategi berbahasa masyarakat Melayu Jambi dalam menyampaikan nasihat-nasihat, petuah-petuah, tunjuk ajar, dan mengkritik atau menyindir serta 
penyampaian nilai-nilai luhur dengan menggunakan bahasa simbolik.

\section{DAFTAR PUSTAKA}

Cassirer, Ernst. 1979. An Essay on Man. Fredericksburg: Book Crafters.

Semiawan, Conny R. 2012. Toward Multicultural Education, International Comference on Multicultrural Education at University of Indonesia. Jakarta: Departemen Antropologi Fakultas Sosial dan Ilmu Politik Universitas Indonesia.

Suyitno. 1984. Sastra, Tata Nilai, dan Eksegesis. Yogyakarta: Hanindita.

Syam, Hasip Kalimudin. 2002. Pokok-pokok Adat Pucuk Jambi Sembilan Lurah: Sastra Adat Jambi. Jambi: LembagaAdat Jambi.

Yundiafi, Siti Zahra. 2010. Syair Saudagar Miskin: Analisis Struktur dan Nilai Budaya serta Suntingan Teks. Jakarta: Pusat Bahasa. 